parts, it appeared almost entirely composed of cells, granular masses, and a little fatty matter. These cells in parts were seen to assume a regular order, so as to resemble fibres. They were in general large sized, containing from one to four wellmarked nuclei and granules, and the great majority of them caudate. Mr. Coulson also exhibited

TWO SPECIMENS OF CARCINOMA OF THE BREAST, one from a man, aged fifty-three, whose mother and paternal grandmother died of cancer. It showed the usual appearances of carcinomatous growth-some gland tissue, and the nipple like a large wart. The disease followed a blow, which he received in August last.

\section{MEDICAL REFORM.}

\section{LETTER FROM W. P. BROOKES, ESQ., TO SIR GEORGE GREY.}

To the Right Hon. Sir George Grey, Bart., Her Majesty's Principal Secretary of State for the Home Department.

Sir,-The delegates from the Provincial Surgeons, or General Practitioners in Medicine, Surgery, and Midwifery, have so recently been favoured, through your kindness and condescension, with an opportunity of expressing personally their views on medical legislation, that $I$ venture most reluctantly to trouble you with any additional remarks on this long agitated question.

I feel it, however, to be a duty which I owe to you, Sir, as well as to the general practitioners resident in the provinces, to make a few observations on the memorial presented to you from the Council of the National Institute of Medicine, Surgery, and Midwifery, bearing date the 16 th of May, 1850, as I consider that document calculated to mislead you on several important points.

Sect. 1st. of the Memorial referred to, from the Council of the National Institute, states-

"That the provincial physicians and pure surgeons, having distinct and separate interests, however competent to advise on matters relating to their own colleges, are neither proper authorities, nor parties sufficiently disinterested, to advise or interfere with the education or the examinations of the general practitioners; and the Council of the National Institute have reasonable grounds for believing that the representations made by the Provincial Medical and Surgical Association are not entitled to be considered the legitimate opinions, or as advocating the true interests, of the general practitioners in medicine, surgery, and midwifery."

In answer to this statement, I beg respectfully to remark, that the provincial surgeons who were represented by delegates in London on the 2nd instant, are not pure surgeons, that, on the contrary, they constitute, in reality-from the general character of their practice, which embraces every branch of the medical profession-the class called, by the National Institute, general practitioners, although known only in the provinces by the title of surgeons. I do not know a single pure surgeon in the country, and the co-operation of a few of the most eminent country physicians, in the endeavour to preserve a satisfactory reform of the existing colleges, is no proof that the provincial surgeons are not what they truly represent themselves to be, - the general practitioners of England,-or that the representatives of this immense body, scattered throughout the provinces, are not entitled to be considered the legitimate opinions, or as advocating the true interests, of the general practitioners in medicine, surgery, and midwifery.

Sect. 2nd of the Memorial referred to, from the Council of the National Institute, states,-

"That the district meetings of the members of the Provincial Medical and Surgical Association, alluded to in their memorial, were very scantily attended,-thirty-two persons only having attended the meeting at Bath, seventeen of whom were either physicians or pure surgeons; at the North Wales branch, held at Wrexham, fourteen persons attended; whilst at Shrewsbury there atterided but ten or eleven. The attendances at the other branches being of a similar character, as to composition and numbers, are yet held up in the memorial as representing the opinions of the general practitioners of England!"

In answer to this statement, I beg to observe, that when a meeting of any society is publicly convened, due notice being given of the object of the meeting, the resolutions of those who attend, and especially where theyare carried unanimously, as at Shrewsbury, are generally considered to express the col- lective opinions of the society or district branch, as the case may be. Were it otherwise, it might with equal reason be urged that a member of Parliament was not duly elected because a portion only of the electors had recorded their votes. In London there is no difficulty in collecting together a large body of medical practitioners; but in the country, where many reside twenty, thirty, or forty miles from the county town or place of meeting, they attend at a great personal inconvenience, especially where there is no communication by railway.

In Shropshire, there are two associations, consisting, with the exception of two or three physicians, entirely of general practitioners-the one being a Medical Reform Association, the members of which were represented at the Home Office, on the 2nd inst., by four delegates, of whom I was one; and a district branch of the Provincial, Medical, and Surgical Association, the members of which were represented, together with those of the other district branches, by Dr. Hastings, of Worcester.

Section 4 of the Memorial of the Council of the National Institute affirms, that the representations made to you on the 2nd inst. by the delegates of the Medical Reform Societies, and of the Provincial Medical and Surgical Association, have not in the least degree invalidated the evidence afforded by the National Institute, that " a new and independent college is the deliberate and most anxious desire of a vast majority of the general practitioners in town and country."

In support of the representations made to you by the delegates from the provincial general practitioners, and by Dr. Hastings, on behalf of those general practitioners who belong to the Provincial, Medical, and Surgical Association, I need only refer you, Sir, to the numerously signed memorials presented at various times, both to yourself and your predecessor in office, Sir James Graham, from the general practitioners of England, and which sufficiently attest their repugnance to a new college, which they consider will inflict a serious injury on the College of Surgeons, and to the establishment of which they look only as a last resource, and when all their efforts to effect a satisfactory reform of the College of Surgeons have proved unavailing.

Were the College of Surgeons re-established on a more extended representative basis, with an examining board in medicine, midwifery, and pharmacy, provincial fellows no longer excluded from the Council, and the small existing remnant of pure apothecaries registered, and licensed to practise as surgeons, the demand for a third college would cease entirely, and the College of Surgeons become the most important and flourishing medical and surgical institution in the world.

The principal obstacle to the attainment of this object is the ungenerous wish still entertained by the Council to exclude from a share in the government of the College those fellows who reside more than five miles from the General Post-office in St. Martin's-le-Grand, or whose prescriptions are dispensed at their own surgery, which I consider the safest and most appropriate place for the preparation of those remedies which require great care and accuracy in the country, where competent chemists are not always to be found.

The members of the College of Surgeons still entertain a hope that the Council, if so advised by you, Sir, will yet yield on these points, and thus put an end to the discord and agitation which has so long prevailed in the medical profession.

It is very gratifying to find that the general practitioners in medicine, surgery, and midwifery, belonging respectively to the National Institute or to the Provincial Associations, are unanimously agreed on the necessity and justice of such a standard of medical, surgical, and general education, as will secure to all classes, poor as well as rich, practitioners qualified for all the emergencies of medical and surgical ministrationan opinion in unison with a resolution carried unanimously at a congress of several hundred medical delegates, from all parts of France, assembled, under the presidence of $\mathbf{M}$. Serres, at the Hotel de Ville, Paris, on the 5th of November, 1845, and which was to the following effect-- That it was not expedient to have an inferior grade of medical practitioners, and that the institution of officers of health was illegitimate and dangerous; consequently, that this inferior grade ought to be abolished. I have the honour to remain, Sir,

With profound respect,

Your most obedient servant,

W. P. BKOOKES.

One of the Delegates from the general practitioners or sur-

Much-Wenlock, May 29, 1850. of Salop. 